DOI: 10.52837/27382702-2021-34.1-101

\title{
GENERATIONS OF WARFARE AND THE FUTURE OF THE HYBRID WARS*
}

\author{
Artsrun Hovhannisyan
}

\begin{abstract}
The article is about the generations of war and expounds on Hybrid wars. Its connection to the model of generational divisions is detailed. Today, as well, with the Cold War is over, the hyperactivity of the US in the military-political arena has brought forth a similar storm. The American war machine is in a victory march. At the same time a variety of ideas and theories of war are brought forth and being discussed. There are differing views on how generations of war should be classified. In my opinion, the main spheres of human development, such as that of commerce, economics, politics, science, education and culture, are the main determining factors. Taking into consideration the various factors, wars have been divided into the following six generations. Fifth generation warfare's necessity became apparent during fourth generation wars. The main elements in question were automated control systems and precision-guided armament. Along with new political, economic and social developments, these ensured new victories. Again, in this generation, armies chose to avoid operations that required large scale mobilization, and instead tried promptly sending small groups into battle, avoiding large-scale preparatio. The issues in the fields of war, as well as the issue of waves of communication, reached their peak. This generation, once and for all, confirmed the importance of force accumulation on any platform, anywhere in the world. Fifth generation wars brought armies to a point where they retired from classical combined arms warfare; ElectroFire Battle is more commonly applied. Trenches and engineered structures are nearly extinct. This was yet another example of believing in the superiority of quality over quantity. The effects of information became a decisive factor. These were the wars of the digital media industry.
\end{abstract}

Keywords: Generation, warfare, electro-fire Battle, digital media industry, precisionguided armament, air force, attack, defence, USA, control systems

\footnotetext{
* The article was submitted on May 10, 2021: The article was reviewed on May 20, 2021.
} 
After major geopolitical changes and shocks, new forces always emerge, or one of the old superpowers gains more power and starts a new phase of active military-political work with new attacks. This in turn results in a period of large-scale practical and theoretical review and evaluation of the principles and regulations in the field, which in turn brings forth new proposals. There was a similar period after the French Revolution and the Napoleonic era with Carl von Clausewitz and the general rise of thought in German military science. The periods after the two World Wars were similar, and they resulted in an abundant flow of new military theories by Fuller, Foch, Guderian, Tuchachevski, Hart and others.

Today as well, with the Cold War being over, the hyper-activity of the US in the military-political arena has brought forth a similar storm. The American war machine is in a victory march. At the same time a variety of ideas and theories of war are brought forth and being discussed. It is hard not to see the high ambition, stretched projections, and unbelievable developments of wars as discussed in the works of Clark, Luttwak, Toffler, Cebrowski, or Krefeld. Today, "irregular wars," "hybrid wars," "information wars," "cyber wars" or "bloodless wars" are terms that are in fashion. However, as always, these suggestions and predictions become more modest and moderate over time. Those maximalist predictions will return to reality, bringing with them interesting, important, yet moderate innovations and solutions.

Wars go through a cycle where an era of wars of exhaustion is followed by an era of lightning wars and vice versa. Meanwhile, armies with the classically large, exhausting model are being faced with irregular armies or armed groups that are often winning battles against them. This is the result of the military idea of permanent struggle. Sun Tzu, however, says that dragged out wars are not favorable. They exhaust the soldiers and the nation. This idea has been well examined by staffs, who usually give preference to short-war planning.

Army structure, tactic, readiness, numerous security factors, etc. are subject to the following two models: Firstly, small-scale forces executing fastpaced operations, and secondly, slow-paced operations conducted by large 
forces. In other words, we have blitzkriegs or wars of exhaustion. Their proportion is a separate topic of discussion. Often, small armies with highreadiness attack and defeat armies that operate with large numbers ${ }^{1}$.

Authoring main innovations in military science, victorious are the armies that accomplish short-term operations. The point is that such armies, which give great value to high readiness, knowledge in the field, and constant creative thinking, are innovating.

In the initial phase of a battle or war, better prepared, skilled armies are more successful. However, in the following stages, armies that are illprepared, yet with more resources, might gain prevalence. By their nature, all leadership plans initially suggest complete defeat of the adversary with rapid, victorious operations, but a number of political and military factors make those operations prolonged.

There are differing views on how generations of war should be classified. In my opinion, the main spheres of human development, such as that of commerce, economics, politics, science, education and culture, are the main determining factors. Taking into consideration the various factors, wars have been divided into the following six generations:

First generation wars were those of the Ancient World and Medieval times, before the introduction of firearms, namely the era of cold weapons bows and arrows. The wars of this generation are from the period up to, and during feudalism. Of course, these wars are further divided into sub periods which take into account, for example, the emergence of a new army division or the application of new methods ${ }^{2}$.

Second generation warfare is determined by the introduction of firearms, which completely changed the range and scale of destruction.

\footnotetext{
${ }^{1}$ Mockaitis 1990: 10-29; Galula 1964: 8-39.

2 This, as well as the other changes, are considered separate generations of war by some analysts. However, I do not share this opinion because these solutions didn't bring forth such significant changes in military art as later did the gunpowder, internal combustion engine, jet engine, nuclear energy or digital technologies. Of course, there were some revolutionary solutions for various problems, but they simply did not result in major systematic changes.
} 
Certainly, these wars developed over long periods of time, and they are such that they can be divided into sub-classifications, yet those are merely parts to the whole. For example, the multi-shot rifling guns that appeared at the end of the 1800s, compared with the first ever firearms, gave completely different possibilities to the military. At the turn of the $20^{\text {th }}$ century, the improvement of firearms had a significant impact on the arts of combat, yet we maintain that this was merely the further development of second-generation wars.

Both of the above two generations of war lasted multiple centuries. Accordingly, their respective sub-periods were also long and often spanned over many decades. In the case of both generations, the primary attack on the battlefield was delivered by live force. Operational art was just being born, and wars were fundamentally wars of exhaustion using linear tactics. Finally, these two generations were also directly linked to the agricultural economy of the time.

Third generation warfare was that of the locomotive, internal combustion engine, automatic firearm, and coordinated artillery. It was an era of mechanical development. With regard to their volume, these wars were on a completely different level. These were world wars. The concept of rear disappeared. The volume and speed of maneuvers were unprecedented. Death tolls reached millions. In the Combined-arms warfare was clearly formed in military art. The theater of war expanded, and communication lines were pulled across nearly the planet. These are the wars of the industrial era. In other words, the political developments were inspiring the nature of new wars. From a purely military point of view, this is the era of Napoleonic and German military schools, the latter having developed under the influence of the former.

At the end of each warfare generation, core characteristics and resources of the next generation come forth. The features of third generation warfare reached their peak during World War II, but we continue to see their manifestations to this day. Third generation wars stood out with informational 
and advocacy factors coming to light ${ }^{3}$. It moved on from the distribution of leaflets to the use of radio and television ${ }^{4}$.

Fourth generation warfare's primary features had already emerged at the end of WWII. It was an era of new technological solutions, era of invention of new physical phenomena, such as nuclear energy (both as a weapon and reactor) and the jet engine were. Local management systems emerged. It was these factors, as well as the strong ideological and new political-military alliances that established the general guidelines for fourth generation warfare, that is, small-scale, fast-paced wars ${ }^{5}$ where armored forces and vast artillery of the previous generation gradually lost their prominence (yet engineered structures continued to grow in importance). With respect to the informational factor, this was the era of television. In fact, the American army was defeated in Vietnam because of it, and also because the military mind, overly engrossed in nuclear weapons, didn't properly make enough room for the informational element in their plan ${ }^{6}$.

Fifth generation warfare's necessity became apparent during fourth generation wars. The main elements in question were automated control systems and precision-guided armament. Along with new political, economic

\footnotetext{
${ }^{3}$ After printing/publishing, wide usage of the radio brought the first large-scale informational operations, which were during WWI. Informational preparations were clearly established prior to any military operation.

${ }^{4}$ Napoleon's publications, musical and theatrical propaganda yielded to Goebbels' radio and films with nearly live stream on American television. In the next generation of warfare, this led to the defeat of the US in Vietnam, which was the first victory of the informational factor over other combat factors.

${ }^{5}$ In general, the speed of operations increased from generation to generation, because that is what overcoming the rules for that warfare demanded, and technical means were being invented for this reason.

${ }^{6}$ After conducting a study of the Vietnam War, American theorists discovered an interesting fact. During WWI the ability to transfer data was 30 words per minute while 4,000 soldiers covered $10 \mathrm{~km}^{2}$ of defense zone. During WWII, information flow doubled while human density slightly decreased. During the Arab-Israeli War (1960s), data exchange was 50,000 words per minute while the defense density in the same area was 150 soldiers. Finally, in 1991, it was possible to transfer 192,000 words per minute while the manpower density was 23.4. Thus, there is a correlation where the higher the capacity of information exchange, the less manpower is needed for solving the problem.
} 
and social developments, these ensured new victories. Again, in this generation, armies chose to avoid operations that required large scale mobilization, and instead tried promptly sending small groups into battle, avoiding large-scale preparations ${ }^{7}$. The issues of the fields of war, as well as the issue of waves of communication, reached their peak. This generation, once and for all, confirmed the importance of force accumulation on any platform, anywhere in the world ${ }^{8}$. Fifth generation wars brought armies to a point where they retired from classical combined arms warfare; Electro-Fire Battle is more commonly applied. Trenches and engineered structures are nearly extinct. This was yet another example of believing in the superiority of quality over quantity. The effects of information became a decisive factor. These were the wars of the digital media industry. This was the era when data was exchanged via computers. In this era, we saw more instances of irregular combat operations, which were to become more frequently applied in the following generation of warfare, where combat groups involved are small, mobile, and well-equipped, and they run battles that are not bound by management of hierarchical structures. That is the hybrid war. And without a doubt, this era belonged to the American military school.

Sixth generation warfare also brings us new key features. The politicalmilitary features that underlie the requirements of sixth generation wars are the following: In the 50s the British theorist Liddell Hart described and promoted the "Indirect Approach" military strategy, which, in essence, at the strategic level, was the same as what we described being used in US and UK

\footnotetext{
7 Of course, few have succeeded in this, and as a phenomenon in military art, it is exceptional.

8 The US, which initiated this generation, gained ultimate supremacy in air, water, land and space. The issue of securing communication between the various war arenas is of strategic importance. It was the Macedonian who moved the war arena to another continent, securing a period of war that was an operational success in terms of depth. However, it was purely on land. Prior to that, the Parthians had already gone to other continents, but they had not gone deep. Later, Rome repeated this and also tried it by sea. Complete intercontinental communication channels were established by the British. But it was only the US that was able to establish complete, developed world-wide communication channels, in sync, on land, air, sea and space. Today, the US is the only power that can conduct combat operations on all mentioned dimensions, on any point of the globe, rapidly gathering all the necessary forces.
} 
geopolitics. This theory was already in use long before it was presented as it was, but after its promotion, it became widely applied on the operational and military levels. These are strikes that bypass the firm defensive positions of the enemy. They are activities that are meant to distract the adversary and throw him off balance. The West (and specifically the British and American militaries and their military-political machines) is making more and more use of this approach. The indirect approach will also be more applicable in new generation wars thanks to new technical possibilities.

Many include conflicts of global politics to fall within the definition of "War". For example, the West's sanctions against Russia and North Korea, or the race between US and China, would be examples of war under this definition. Politically, it may be acceptable to speak this way, and the term "hybrid war" is frequently used in that sense. However, by standards of classic military science, this definition is completely wrong. Such phenomena, at most, can be referred to as "conflicts," which may include certain combat actions. The specialists who argue for such a broad definition of "war" bring as an example the longstanding conflict between the West and the Soviet Union, cleverly pointing out that the situation was referred to as the "Cold War" even though, they assume, there was no direct fighting. However, in my view, that is not a relevant example because during the Cold War there were, in fact, many real combat actions and direct clashes between the USSR and Western countries. At first, they took place in territories of other countries, but there were clashes within Soviet territory as well. I contend that conflicts that mainly focus on the economy, politics, or propaganda, and not on the military, are not wars, and it is wrong to refer to them as such. Antagonism is a category of politics, which is on the political plane of those who order wars, and it may be longer, deeper, and undertake multiple wars, or it may not. Yet, these days many incorrectly refer to such situations as "hybrid wars".

The irregular operations and battles are the foundation of the Hybrid war while the mixture of regular and irregular operations is sometimes called a complex structure. This is true but temporary as wars become sophisticated in 
one way or another from generation to generation and they can emerge as one after the establishment of the new generation.

These expected irregular combat actions mean the use of well-trained forces working in small numbers. Commonly, for a generation's wars whose intrinsic military systems and rules are fixed for a long period of time, their shortcomings give birth to a counterweight system. Primarily, military systems whose armies were distinguished by quantitative characteristics $\left(3^{\text {rd }}\right.$ or $4^{\text {th }}$ generation wars) were replaced by military systems with distinguished qualitative features $\left(5^{\text {th }}\right.$ or $6^{\text {th }}$ generation wars). Military systems based on the qualitative $\left(5^{\text {th }}\right.$ or $6^{\text {th }}$ generation wars) will later be replaced by systems based on the quantitative again $\left(7^{\text {th }} \text { or } 8^{\text {th }} \text { generation }\right)^{9}$.

Of course, this does not entail that all new generation wars will be fought based on quality, or that they will reject all traces of quantity. Rather, it is about which trends will be prevalent.

\section{Issues of New Generation Warfare}

The first half of the $21^{\text {st }}$ century coincides with a period of transition. What we are witnessing is the state of transition from fifth to sixth generation warfare, and this is called "hybrid," "transitional," etc. The widely used "irregular warfare" is an inaccurate term. It was first put into circulation by the British Colonel Charles Colwell, but with a correct explanation. In its current use, the term is distorted ${ }^{10}$. This was later established in American military documentation ${ }^{11}$.

\footnotetext{
${ }^{9}$ At the end of the second generation warfare, armies had become such that they possessed characteristics of extremely high quality. Knights, left over from the feudal system, were individually of high quality. Each of these knights, served by dozens of people, meant these military units were massive and sluggish. They became extinct under the pressure of the new model of mass armies. Of course, any new generation has the feature of new technology, but what underlies a generational shift is the difference between models.

${ }^{10}$ Callwell 1990: 21.

11 U.S. Marine Corps Combat Development Command, June 2006, Tentative Manual for Countering Irregular Threats: An Updated Approach to Counterinsurgency Operations (Quantico, Va., June 7, 2006), p. 1.
} 
The war may emphasize transitional, hybrid and irregular combat actions. However, we should keep in mind that they need to be brief, because prolonging them eventually makes them regular. The point is that irregular combat actions are viewed as a retreat from classical combat operations. It is seen as a new phenomenon of unusual, irregular fighting style, or as some effective way for fighting against classical war machines.

This is not a contradiction of old and new wars but rather a transition which displays parts of both old and new generations. Irregular combat operations are a recurring phenomenon in warfare, which, however, do not single-handedly ensure a victory. If an army is incapable of switching to classical regular operations in situations that require it, it can not $\operatorname{win}^{12}$. That is, the transition from irregular to regular and vice versa must be smooth and constant. This will mean that the army is capable of using old methods and styles, and it has also adapted to the new, incomplete one. This is the only way that armies can defeat such powerful enemies ${ }^{13}$.

I believe that a number of the definitions of "irregular wars" and "irregular actions" have a short life ${ }^{14}$, and that is a problem.

The definition of "hybrid war" that I propose resolves the above problem. A hybrid war is the mixture of old and new, regular and notyet-regular combat actions and methods that are used on a given occasion as a temporary solution. It is constant, yet a flexible solution for the occasion, as it is able to change its environment and how it manifests itself. In the near future, these displays of the old and new generations, once refined, will unite to form a new, distinct generation of warfare.

At the same time, however, in certain situations they can appear separately, or somehow go astray. Currently, this merger, this refinement of

\footnotetext{
12 Gray 2007: 30-41.

13 Hoffman 2007: 7-13, 43; Biddle Stephen and Jeffrey A. Friedman "The 2006 Lebanon Campaign and the Future of Warfare: Implications for Army and Defense Policy" Carlisle, PA: US Army Strategic Studies Institute, September 2008) <http://www.globalsecurity.org/military/library/report/2008/ssi_biddle-friedman.pdf>

${ }^{14}$ Joint Warfighting Center. Irregular Warfare Special Study. Norfolk, Washington D.C.: U.S. Joint Forces Command, August 4, 2006, pp. 2-3.
} 
the irregular and its transition to the regular, has given birth to a new scientific dispute. From this, some specialists have coined the term "compound wars" 15 . However, we believe that this is the result of not properly understanding the time-consuming merging process and the formation of a new generation.

Strategies of new generation warfare will be fully dependent on the global economic system, where anything is possible to dictate through the governing model of "soft power," which involves convincing, providing proof, somehow creating dependency, and so on. Superpowers execute even direct military invasions with the blood of others.

However, operations executed with such small groups may also last long. We noticed this towards the end of 2014 in Iraq, similar phenomena could be observed also in Ukraine. This gave birth to the expression, "green people," or troops without distinctive badge. The number of people and the quantity of military equipment exceeded tens of thousands, yet there were no clear borders or defining trenches of sides.

Below are some important, distinctive features of combat actions associated with irregular or so-called hybrid wars.

1. The structure and quantity of units are non-classical.

2. There is quick status change of units and their members from civilian to military and vice versa.

3. There is no clear subjugation with regards to a hierarchical structure.

4. There are no clear systems of rear or supply.

5. There are no clear military lines or divisions during combat actions, but rather they are more target-oriented actions, especially around infrastructures.

6. Operations are decentralized.

7. There is a lot of mobilization.

8. There is limited bias in the use of force types. That is, an equal number of infantries, artillery or other divisions are used.

${ }^{15}$ Williamson, Mansoor 2012: 3-7. 
9. There is flexibility to transition from classical to guerilla warfare, to subversive actions, and back.

10. There is minimal use of classical combined-arms battle (and often its portions are supplemented with a substitution force type), yet there is high capability when it becomes necessary to put this play in action.

11. There is flexibility for a quick change in plans at tactical as well as operational levels, all while clearly safeguarding strategic plans.

These are the precepts of new warfare and combat operations that differ from predecessors and, particularly, from guerilla actions.

At this point we can see the synthesis of irregular actions and regular classical warfare more. We may soon witness these characteristics in the transitional wars between the fifth and sixth generation. This is what is properly referred to as "hybrid warfare".

For the sake of invulnerability, irregular groups often work separately, change their names, positions, and commanders, and sometimes they may take responsibility for the actions of another. Although these wars and combat actions definitely have similarities with ordinary guerilla actions, they are certainly not a complete duplicate. Scientific debates on this issue are now held everywhere. Chinese military theorists call this warfare "unrestricted military operations". It is hard to say whether this expression correctly captures this new warfare, as there have been plenty of wars in previous generations where military operations were also unrestricted.

Similar "low-intensity" combat operations (as it is accepted to call in the West) will later be conducted by such armies, supranational military organizations, whose modus operandi will be characterized by the above listed innovations. These groups may be used by governments, but being that they are not regular armies, they will become increasingly more self-reliant and unpredictable organizations.

Such wars may last long mainly because of inequality between the sides and because they will be conducted in an irregular manner ${ }^{16}$. The long and

${ }^{16}$ Borum 2011: 35-45; Mitchell 2010:89-97. 
non-intensive conflicts will also solve strategic problems. They will be conducted suddenly and, in several places, simultaneously, and being components of strategic moves, they will be used by powerful economic alliances to exhaust their rivals. These are the political, economic, social and scientific foundations which will determine the rules of sixth generation warfare.

The main factors of this generation are informational-psychological, technological and nanotechnological, which defeat the enemy without physically wounding them. In the near future, battles will likely be NetPlatform Centric ${ }^{17}$, which are managed and interconnected by network and attacks from platforms, and even further development may lead them to be informational-psychological wars where the main weapons may be nanoweapons and biological-weapons. Initially such warfare can appear in the form of cyber-attacks and operations. The early successes in this field brought forth some exaggerated views on cyber wars; however, time has revealed that, at best, these are just war platforms or large-scale operations, but in no way are they yet complete wars on their own.

Any new generation of warfare, even when it fully replaces the previous generation, will have adopted features from the previous generation. New generations are always enriched by the old ones. Methods, mediums and ways are often repeated in new generations. The nature of war has not changed. In other words, when we say that the influence of machine guns, tanks and artillery will not disappear suddenly with a newer generation, or will even remain in that new generation, we are talking about the features of third and fourth generation warfare. Along with the rekindling and magnification of combat operations, there will be a certain degree of return to classical warfare (not completely classical, but rather a synthesis). The irregular will be refined and will become common. Hence, it can be assumed that the transition from one generation to another is evolutionary and represents a link between the

\footnotetext{
${ }^{17}$ We explain in further detail what Electro-Fire Battles and Net-Platform Centric Wars mean in other work.
} 
old and the new rather than a borderline separating the two. It is, consequently, based upon the innovative character of operational change and development.

Those technical innovations have become the basis for generational change, and in turn, wars, as huge clients, have caused the further development of those innovations. All technical innovations which have ensured generational change, while enabling military theorists to conduct lightning model wars, have continually been hindered by political clients (who are, in a sense, the "owners" of wars); and here lies the main misconception. Carried away by the possibilities of new weapons, servicemen and scientists believe quick victories, or that just one strike is enough. However, it is the political considerations of the clients of war that determine whether the war will end quickly or not (and even if sometimes it is determined by circumstances, they are nevertheless political). To say that it is politics that decides the model of wars, or its course, is to say that it is the big strategy which determines the military-arts and tactical models. Although it is true that a good military system can conduct blitzkrieg wars, it is directly dependent on the political situation, stability, etc.

In war, the biggest mistake of commanders and leaders, which, as a rule, have led them to defeat, has been the fact that they had prepared only for wars like those from the past. Not all military commanders realize the nature and requirements of new generation warfare. A commander may have become a hero in previous wars, or conducted operations brilliantly, yet that commander may not have any understanding of the nature of future warfare. Even with his great talent and bravery in WWI, General Ludendorff could not understand the nature of new warfare. By continuing to emphasize the role of the infantry, he did not see the important role of land or mobile forces ${ }^{18}$. In the 1930s, a significant portion of Soviet servicemen who had gone through a civil war had the same problem.

${ }^{18}$ Bezil 2012: 303. 
The strategy of new generation warfare will not have major changes either. The countries or alliances with strong, self-sufficient economies, comprised of numerous elements, will be powerful. These economies will be dominating others, and they will also produce the apparatus of the future. Today, America is switching from large factories with smokestacks to an economy that produces high-tech products, and nearly none of those factories have such smokestacks. America is a leader in the production of electronic devices such as computers, phones, high-quality batteries, various electrical appliances, electrical cars, 3D-printers, and the biggest, as well as the largest number of, civilian aircraft.

In the future, the countries that will be powerful will have a stable political system as well as a strong cultural and value system. That is, they will have faith in their strength and believe they are special. Morale, will-power is among the key factors and applies even at the strategic level. These are the necessary basic conditions for being powerful. And changes, too, are necessary, in order to correctly understand the essence of the future.

The main problem on the strategic and tactical levels of the new generation wars, including those in the coming $6^{\text {th }}$ generation, is the rapid development of situations and the quick change of rules, which leave no time for situational decision-making. And new innovations are quickly outdated. This issue of quick changes, which is, in fact, one of the most serious problems in hybrid wars, is also the key to future victories, whose secret is not understood by all. As the great Italian military theorist Giulio Douhet says, "Victory smiles upon those who anticipate the changes in the character of war, not upon those who wait to adapt themselves after the changes occur." Those changes are linked to globalization, interconnectedness (which results in the formation of large blocks and alliances), dramatic growth of populations, dramatic developments in technology, and the drastic decline of moral and spiritual values. All of the above-mentioned points us toward the emergence of new forces, accordingly toward competition and wars for influence over new areas. However, this also implies changes in how the nature of war is 
manifested, at least superficially, as the so-called "civilized and bloodless" wars.

In the Old World, those armies that were capable of conducting an organized mobilization and maneuver of troops gained predominance. The Macedonian did that, and maneuvered through Asia Minor and entered a new world. Napoleon organized maneuvers of huge armies throughout Europe's territories. As for the British hegemony, it was the result of continental communication established by the Navy. Today, the most powerful army in the world enjoys that title, again thanks to the fact that for the first time in human history it is capable of transcontinental maneuvers with the world's largest expeditionary army, leaving no corner on the planet out of reach.

Force concentration, formation and particularly the old rules and speed of maneuvering, are rapidly changing. It is important to understand their essence, and moreover, to foster these changes. To look forward, to see the future, to build the future, means having dreams and aspirations. Human history has repeatedly confirmed that victory belongs to those who have dreams and chase after them.

\section{BIBLIOGRAPHY}

Bezil L. G. 2012: Strategiya nepryamykh deystviy, Moskva (In Russian).

Biddle S., Friedman J. A. 2008: The 2006 Lebanon Campaign and the Future of Warfare: Implications for Army and Defense Policy" Carlisle, PA: US Army Strategic Studies Institute, September <http://www.globalsecurity.org/military/library/report/2008/ssi_biddle-friedman.pdf>

Borum R. 2011: Seven Pillars of Small War Power, Military Review. 2011. July-August, 35-45.

Callwell Ch. E. 1990: Small Wars: A Tactical Textbook for Imperial Soldiers, 3rd edn (1906; Repr. Novato, CA: Presidio Press).

Galula D. 1964: Counterinsurgency Warfare: Theory and Practice, Westport, Connecticut: Praeger Security International.

Gray C. S. 2007: Irregular Warfare: One Nature, Many Characters, Strategic Studies Quarterly, 35-57.

Hoffman F. G. 2007: Conflict in the 21st Century: The Rise of Hybrid War, Arlington, VA: Potomac Institute for Policy Studies. 
Joint Warfighting Center 2006: Irregular Warfare Special Study. Norfolk, Washington D.C.: U.S. Joint Forces Command, August 4. https://www.history.navy.mil/research/library/online-reading-room/title-listalphabetically/i/irregular-warfare-special-study-2006.html

Mitchell K. 2010: Ungoverned Space: Global Security and the Geopolitics of Broken Windows, Political Geography 29, 289-297.

Mockaitis Th. R. 1990: British Counterinsurgency 1919-60, New York: St. Martin's Press.

U.S. Marine Corps Combat Development Command, June 2006, Tentative Manual for Countering Irregular Threats: An Updated Approach to Counterinsurgency Operations (Quantico, Va., June 7, 2006), 10-20.

Williamson Mansoor P. R. 2012: Hybrid warfare: Fighting Complex Opponents from Ancient World to the Present, Cambridge University Press.

U.S. Marine Corps Combat Development Command, June 2006, Tentative Manual for Countering Irregular Threats: An Updated Approach to Counterinsurgency Operations (Quantico, Va., June 7, 2006), № 1. p. 167.

Artsrun Hovhannisyan

$\mathrm{PhD}$, Military Analyst arcrunhovhannisyan@gmail.com

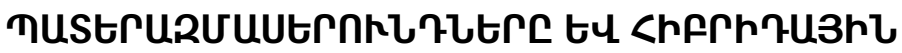 TuStruRUutrh uTUqu乙}

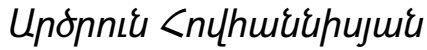

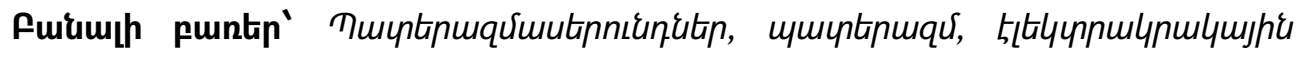

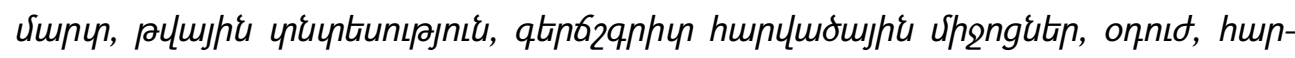

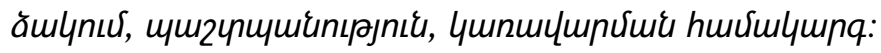

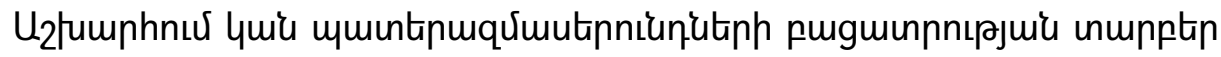

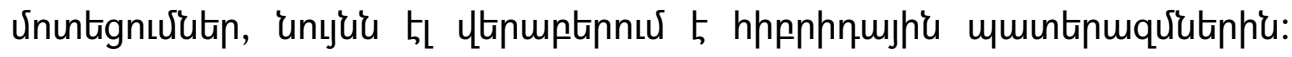

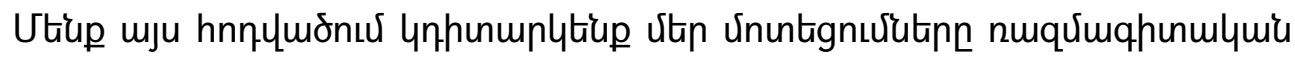
uju punn hungtinh $2^{\text {nıng: }}$ 


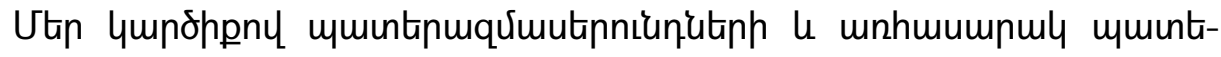

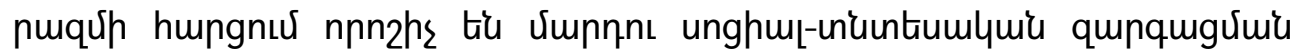

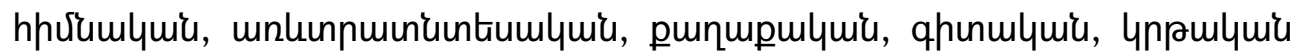

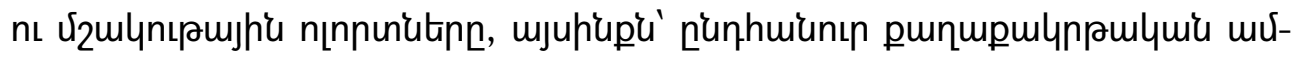

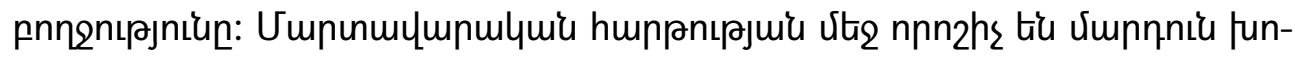

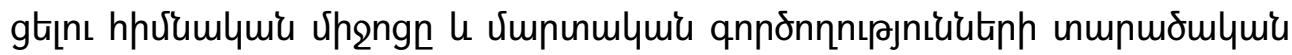

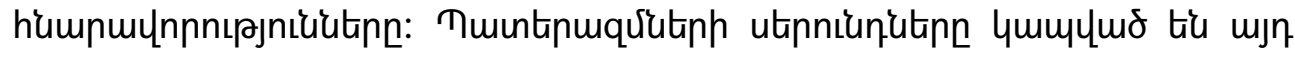

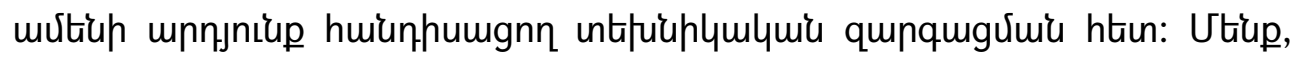

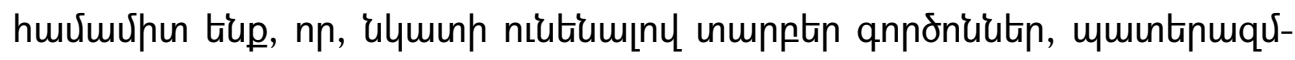

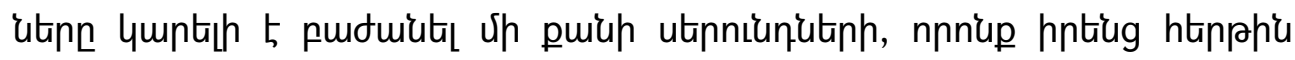

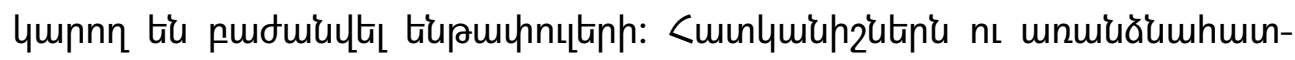

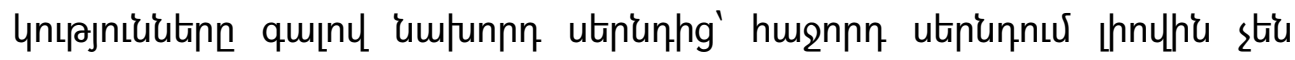

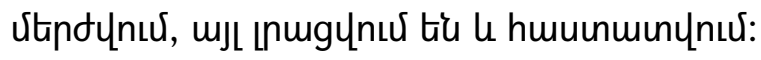

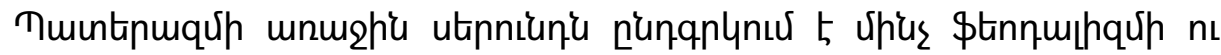

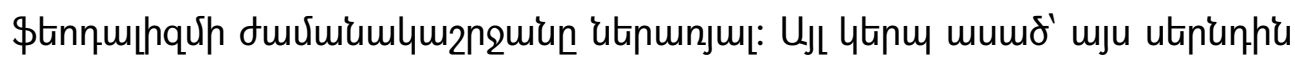

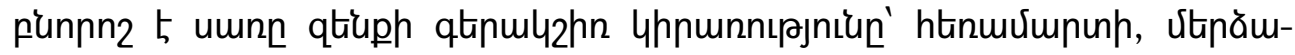

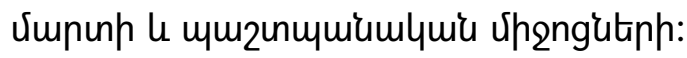

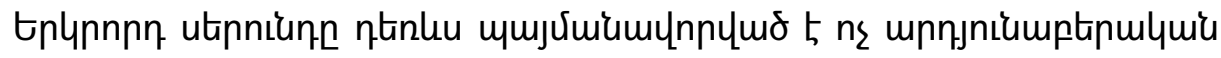

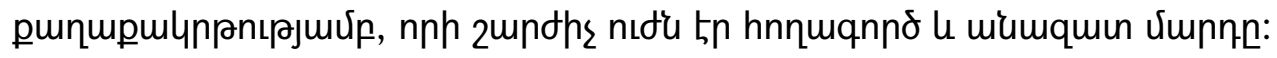

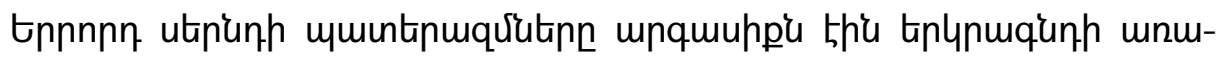

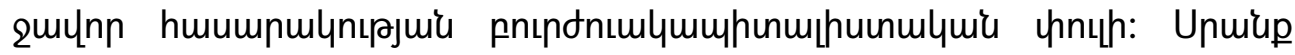

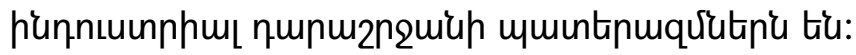

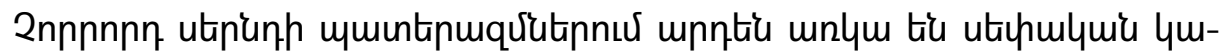

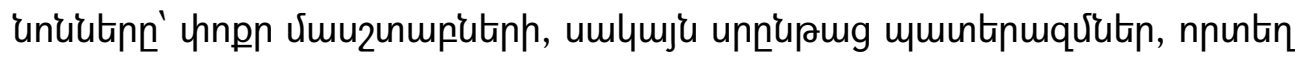

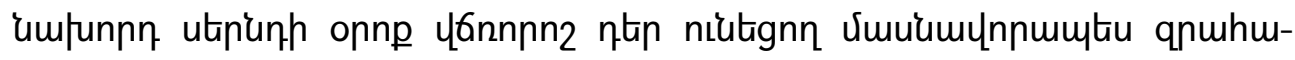

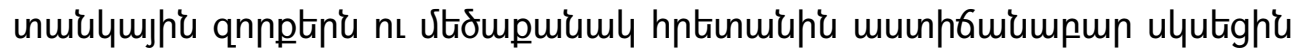

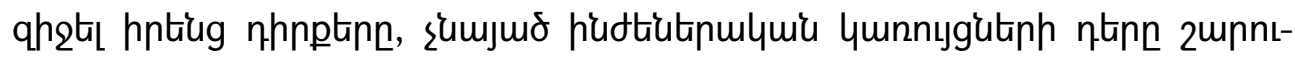

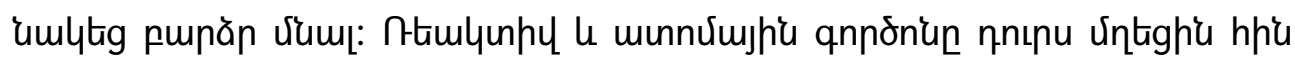

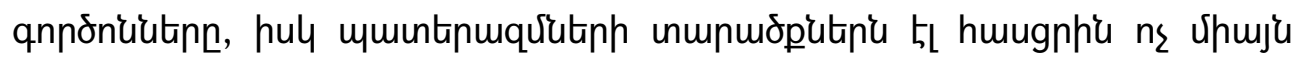

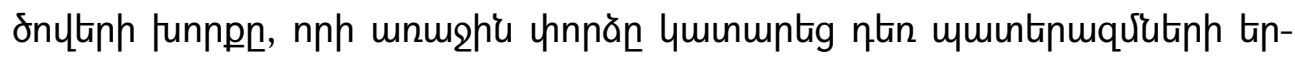

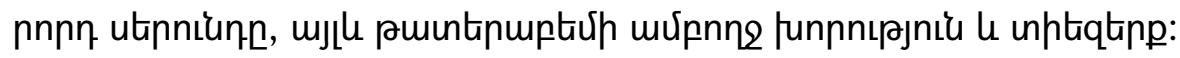




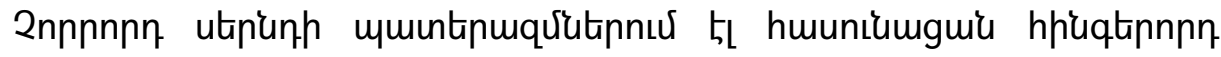

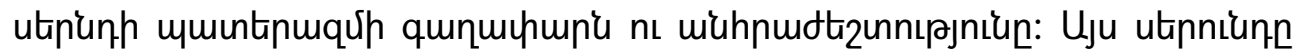

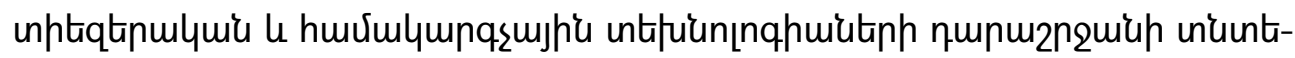

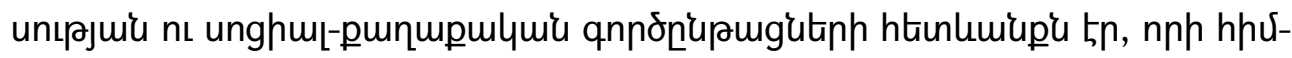

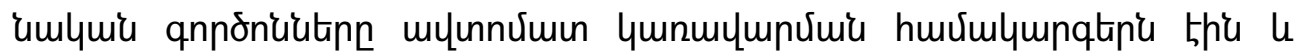

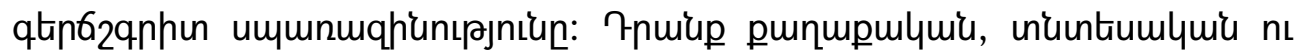

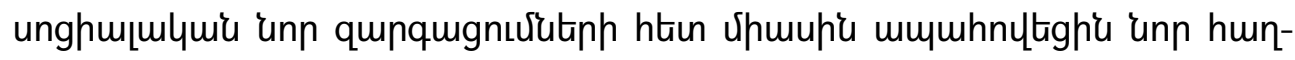
puitulitutip: 